\title{
28 Research Square \\ Ultrasound assessment of central venous pressure: A systematic review and meta-analysis
}

\author{
Jean Deschamps ( $\nabla$ jean3@ualberta.ca ) \\ University of Alberta https://orcid.org/0000-0002-4872-3334 \\ Jed Lipes \\ McGill University \\ Andrew Weinstock \\ McGill University \\ Dev Jayaraman \\ McGill University \\ Lawrence Rudski \\ McGill University \\ Jonathan Afilalo \\ McGill University Faculty of Science
}

\section{Research}

Keywords: ultrasound, echocardiography, right atrial pressure, central venous pressure, systematic review, meta-analysis.

Posted Date: December 17th, 2019

DOI: https://doi.org/10.21203/rs.2.18820/v1

License: (c) (i) This work is licensed under a Creative Commons Attribution 4.0 International License.

Read Full License 


\section{Abstract}

Background Ultrasound is increasingly relied upon to estimate central venous pressure (CVP) in the echocardiography lab and using point-of-care systems in the intensive care unit and the emergency department. However, there is uncertainty regarding the diagnostic accuracy of ultrasound-based parameters as reported in diverse studies. Methods A systematic review was performed by searching MEDLINE, EMBASE, and the Cochrane Database for studies evaluating ultrasound-based indicators of filling pressures in relation to catheterization-based CVP. Studies were screened for predefined inclusion criteria and rated for quality by duplicate observers. Standardized correlation coefficients for each ultrasound-based indicator were meta-analyzed using a random effects model.Results 3949 articles were screened and 64 met the criteria for inclusion. Inferior vena cava (IVC) diameter was assessed in 34 study measures and the pooled standardized correlation with invasive CVP was 0.74 (95\% $\mathrm{Cl} 0.63$ to 0.84 ). IVC collapsibility was assessed in 20 study measures and the pooled standardized correlation with invasive CVP was -0.57 (95\% $\mathrm{Cl}-0.70$ to -0.44$)$. Tricuspid E/Ep was assessed in 6 study measures and the pooled standardized correlation with invasive CVP was 0.59 (95\% $\mathrm{Cl} 0.26$ to 0.93 ). IVC parameters but not E/Ep remained correlated with CVP in mechanically ventilated patients, including cardiac surgery patients. Results were similar in studies featuring non-traditional users and cardiac specialists.Conclusions Echocardiographic IVC diameter, collapsibility, and tricuspid E/Ep ratio are significantly correlated with invasive CVP, albeit with important heterogeneity between studies. Most of these indicators are equally valid when applied in ventilated patients and by non-traditional users.

\section{Introduction}

Volume assessment is a fundamental component of the clinical exam in the office, ward, and critical care settings. Classical teaching has relied on the physical examination of the jugular venous pressure waveform (JVP), although its modest sensitivity of $33 \%$ and inter-observer reliability have increasingly led to the use of other tools $(1-3)$. Invasive methods to assess the JVP, namely, the central venous pressure (CVP), require expertise in installation and interpretation, have inherent risks related to its invasiveness, and can be time consuming $(1-3)$. Although controversial in its utility to predict volume responsiveness, the invasive determination of CVP remains the gold standard in measuring venous filling pressures $(4,5)$.

Non-invasive determination of CVP was pioneered by echocardiographers and largely based on assessment of the inferior vena cava (IVC) using ultrasound systems in the echocardiography lab. Recently, point of care ultrasound systems have been developed and transformed the way physicians in critical care settings evaluate volume status. Newer techniques including 2-dimensional (2D) ultrasonography of the jugular and subclavian veins and Doppler interrogation of the right ventricle have been reported to be useful, although results have been inconsistent (particularly in mechanically ventilated patients) and day-to-day practice continues to rely on basic techniques of IVC size and collapsibility. 
Thus, we performed a systematic review and meta-analysis of the ultrasound assessment of CVP to analyze which techniques provides the most accurate assessment of right atrial pressure in both mechanically ventilated and spontaneously breathing adult patients.

\section{Methods}

A systematic review was performed, searching Ovid MEDLINE(1946-), Ovid EMBASE(1974-), and the Cochrane Database using the search string: (Ultrasound OR Ultrasonography OR Echocardiogram OR Echocardiography OR Echocardiographic OR Doppler) AND ("Central venous pressure" OR "Right atrial pressure" OR "Jugular venous pressure" OR "Fluid status" OR "Volume status" OR "Filling pressure"). References from retrieved manuscripts were scanned for additional articles. English language studies using echocardiography and point of care ultrasound systems in the humans were included between 1980-2017.

Eligible articles were identified through two phases. In the first phase, two authors (JL, AW, or JD) independently reviewed the titles and abstracts of all retrieved bibliographic records for potential inclusion. In the second phase, full texts of the selected articles were retrieved and two authors independently reviewed and selected studies that met the inclusion criteria. Studies were included if right atrial pressure was estimated by ultrasound and directly compared to invasive CVP measured with a fluid filled catheter. Inclusion criteria included prospective and cross-sectional studies of adult ( $>=18$ years of age) human patients, on spontaneous or mechanical ventilation, directly comparing absolute or dichotomized CVP using a fluid filled catheter to bedside 2D TTE or TEE of right atrial pressure, with or without Doppler. Exclusion criteria were studies focusing on congenital, retrospective studies, duplicate studies, and absence of comparison to the invasive CVP reference standard.

Patient characteristics, primary diagnosis, clinical setting, time between ultrasound and invasive measurement, and breathing status (mechanical ventilation or spontaneous breathing) were extracted from the original full text manuscripts. Echocardiographic parameters were recorded as continuous measures with their mean and standard deviation in the normal CVP and abnormal CVP groups, and as binary measures when dichotomized according to a given cut-point. For each parameter, correlation coefficients were extracted and transformed using Fisher's Z-transformation, and then meta-analyzed using a random effects model (STATA version 15). Meta-analyses were performed for all patients combined and subsequently for the spontaneously ventilated and mechanically ventilated subgroups. Heterogeneity was assessed with the I-squared statistic.

Quality of each study was independently analyzed by two authors (J.L, J.D or A.W) using the QUADAS-2 questionnaire for systematic reviews (6). Seven parameters (patient selection bias, patient selection applicability, index test (ultrasound) risk of bias, index test applicability, reference test (invasive CVP) risk of bias, and risk of bias due to timing were scored on a scale from 1 to 3 ; with 1 indicating low risk of bias, 2 indicating moderate risk, and 3 indicating high risk. Aggregate scores were averaged between the two reviewers. A score of 7-10 was defined as high quality, 11-14 as intermediate, and >14 as low. 


\section{Results}

A total of 3949 articles were screened, 159 were identified for full-text review, and 64 met the prespecified selection criteria and were included in our analysis. The 29 studies (representing 34 measures) that reported on IVC size are shown in Table 1, the 19 studies (representing 20 measures) that reported on IVC collapsibility are shown in Table 2, and the 21 studies (representing 27 measures) that reported on right ventricular Doppler or tissue Doppler measures or peripheral vein measures are shown in Table 3 (these are not mutually exclusive as studies often reported on more than a single measure). In all studies, the reference standard was invasively measured CVP, generally performed within 0.5-1 hours from the time of the echocardiographic assessment. The quality of the studies assessed was high with the exception of 10 studies with intermediate ratings $(13,33,34,45,49,56,57)$ and 3 studies with low ratings $(20)$.

For IVC diameter as a continuous measure, 32 study measures were pooled and 2 study measures were not pooled because the $\mathrm{R}$ value was not available $(15,63)$. The pooled standardized correlation with invasive CVP was $0.74(95 \% \mathrm{Cl} 0.63$ to 0.84$)$ with significant heterogeneity across studies (I-squared $77.6 \%, P<0.01)$ (Figure 2). The correlation was similar in mechanically ventilated patients $(0.79,95 \% \mathrm{Cl}$ 0.61 to 0.97$)$ than non-ventilated patients $(0.70,95 \% \mathrm{Cl} 0.57$ to 0.83$)$.

For IVC collapsibility as a continuous measure, 17 studies were pooled and 2 studies were not pooled because the $R$ value was not available $(15,63)$. The pooled standardized correlation with invasive CVP was -0.57 (95\% $\mathrm{Cl}-0.70$ to -0.44 ) (Figure 3 ). The correlation was similar in mechanically ventilated patients $(-0.56,95 \% \mathrm{Cl}-0.77$ to -0.34$)$ than non-ventilated patients $(-0.57,95 \% \mathrm{Cl}-0.69$ to -0.46$)$, with significant heterogeneity in the former (I-squared $88.6 \%, P<0.01$ ) but not the latter (I-squared $36.9 \%$, $P=0.135)$.

Among non-IVC parameters, only E/Ep was reported in at least 3 studies and thus was analyzed. This ratio represents the Doppler-measured trans-tricuspid inflow velocity divided by the tissue Dopplermeasured lateral tricuspid annular velocity. For E/Ep as a continuous measure, 10 studies were included in the analysis. The pooled standardized correlation with invasive CVP was 0.62 ( $95 \% \mathrm{Cl} 0.24$ to 0.99 ) with significant heterogeneity across studies (I-squared 92.7\%, P<0.01) (Figure 4). The correlation was lower and not statistically significant in mechanically ventilated patients $(0.39,95 \% \mathrm{Cl}-0.57$ to 1.34$)$ whereas it was statistically significant in non-ventilated patients $(0.71,95 \% \mathrm{Cl} 0.25$ to 1.17$)$.

The subgroup of cardiac surgery patients was assessed in 8 studies $(10,27,44,70)$ with a total of 547 patients. The 2 high quality studies $(10,27)$ used the IVC diameter in mechanically ventilated patients and had correlation coefficients of 0.81 and 0.86 respectively. The subgroup of non-traditional users (NTU) was assessed in 15 studies, with the majority including both spontaneous and mechanically ventilated patients having a primary diagnosis of sepsis or respiratory failure. In these studies, the correlation coefficients were in keeping with the overall trends observed, ranging from 0.49 to 0.81 for IVC diameter, -0.32 to -0.40 for IVC collapsibility, and 0.62 to 0.84 for peripheral vein measures. Finally, Table 4 depicts the diagnostic performance of binary cut-points for echocardiographic parameters used in certain 
studies, wherein sensitivity ranged from $47-92 \%$ and specificity ranged from $72-100 \%$ for the various ultrasound parameters.

\section{Discussion}

Our meta-analysis encompassing a representative sample of patients and physician users has shown that ultrasound-based estimates of CVP are moderately correlated with invasive measures. In an undifferentiated population, the IVC diameter is the most highly correlated, followed by E/Ep, and lastly IVC collapsibility. The IVC diameter was similarly correlated in ventilated and non-ventilated patients, while the other parameters performed less well in ventilated patients. Given these findings, and the relative ease of measuring the IVC diameter, it is reasonable to utilize IVC diameter as the starting point to determine volume status if invasive monitoring is not warranted or available.

The findings of our meta-analysis demonstrate that the tricuspid E/Ep ratio is a promising parameter. E/Ep performed with moderate correlation in the non-ventilated group of patients. The performance of this test in mechanically ventilated group remains an unknown due the inclusion of only 2 studies in this subgroup of patients and requires further study. Possible reasons for low adoption of this parameter include the technical challenges inherent to performing this test, and the requirement of specialized ultrasound systems capable of performing Doppler and tissue Doppler measurements (which initial point of care ultrasound systems did not uniformly support). As the field of ultrasound continues to evolve from technological and pedagogical perspectives, a larger number of trained users will be equipped to implement the E/Ep and other advanced measures for the estimation of CVP.

Mechanically ventilated patients deserve special attention as they are a challenging subgroup of patients to study, and estimation of filling pressures is likely to be of great clinical relevance. In mechanically ventilated patients, the increased intrathoracic pressure exceeds intraabdominal pressures causing the IVC diameter to be larger than in spontaneously breathing patients. Despite this, the IVC diameter is still positively correlated with RAP (71). Moreover, insufflation during a passive mechanical ventilator-induced breath causes dilation rather than collapse of the IVC (71), rendering an opposite and less predictable correlation with RAP. In our study, the IVC diameter had the highest correlation and the narrowest $\mathrm{Cl}$ of all the ultrasound measures evaluated, while IVC collapsibility had a reduced correlation with a wide $\mathrm{Cl}$, and the E/Ep had a non-significant correlation but included only 2 studies (44), Further study will be required before recommending IVC collapsibility or E/Ep in this group of patients.

Given the expanding interest and use of ultrasound by diverse practitioners, ultrasound-based assessment of CVP in no longer restricted to the cardiologist trained in echocardiography. Accordingly, the proportion of studies with non-traditional users was notable (30\%). These studies generally focused on basic measures such as IVC diameter and reported correlation coefficients in line with those reported by traditional users. These data support the continued dissemination of echocardiographic training among non-traditional users in the intensive care unit, internal medicine, emergency medicine, and other fields. 
Current guidelines from the ASE (72) are in line with the data currently covered in our systematic review and meta-analysis. Most of the studies included a dichotomization of CVP of $>10 \mathrm{mmHg}$ corresponding with an IVC collapsibility $>40-50 \%$. There was some discordance with IVC diameter, in that 3 out of 10 studies had significantly lower IVC diameter cut-off $(17,25)$, but overall most studies had an IVC diameter corresponding to current recommendations.

First, the studies that were identified and reviewed evaluated the accuracy of ultrasound parameters in isolation and did not compare various combinations of parameters which may lead to greater diagnostic accuracy. Second, specific factors may interfere with the reliable use of IVC and right heart parameters as surrogates of CVP: these include tricuspid valve disease, etiology of right heart disease, pericardial disease, and atrial fibrillation. We could not determine presence or absence of these parameters from the published studies.

Finally, although it is important to understand how well ultrasound measures correlate to an invasive CVP, perhaps the more important question to be answered is how well ultrasound measures correlate to volume responsiveness.

\section{Conclusions}

Non-invasive ultrasound assessment of the IVC can be effectively performed at the bedside to estimate CVP and can be performed by cardiologists and non-traditional users across a broad spectrum of patients, including those on mechanical ventilation. Assessment of other parameters such as E/Ep may be complementary if confirmed in additional studies, provided that the expertise and equipment is in place to acquire them. The observed heterogeneity in the studies reviewed highlights the need for further high-quality studies with adequately powered sample sizes to be performed, comparing different parameters and testing the value of an integrated multi-parameter approach for estimating CVP.

\section{Declarations}

\section{Ethics approval and consent to participate}

This systematic review and meta-analysis did not acquire any primary patient data. All data was sourced from other studies. As such, ethics approval was not required to proceed with this study.

\section{Consent for publication}

All authors consent to publication of this manuscript.

Availability of data and materials

This is an Open Access article distributed in accordance with the Creative Commons Attribution Non Commercial (CC BY-NC 4.0) license, which permits other to distributed, remix, adapt, build upon this work 
non-commercially, and license their derivative works on different terms, provided the original work is properly cited and the use is non-commercial. See: http://creativecommons.org/licenses/by-nc/4.0

\section{Competing interests}

None declared.

\section{Funding}

No operating funding was awarded for this project. Dr. Afilalo is supported by grants from the Fonds de recherche du Québec en santé and Canadian Institutes of Health Research.

\section{Authors' contributions}

$\mathrm{JD}, \mathrm{JL}$ and $\mathrm{AW}$ were responsible for the screening, selection and analysis of articles. JD, JL and JA were responsible for drafting the manuscript. All authors critically reviewed the manuscript. JL and JA were responsible for study design and conception. DJ and LR provided expert guidance for interpretation and generalizability of the results. JA was responsible for the statistical methods and analysis. All authors read and approved the final manuscript.

\section{$\underline{\text { Acknowledgments }}$}

No additional acknowledgments.

\section{References}

1. Batllori M, Urra M, Uriarte E, Romero C, Pueyo J, López-Olaondo L, et al. Randomized comparison of three transducer orientation approaches for ultrasound guided internal jugular venous cannulation. Br J Anaesth. 2016 Feb;116(3):370-376.

2. Gerling V, Feenstra N. Two Serious Complications of Peripherally Inserted Central Catheters Indicating the Need to Formalize Training for Placing Central Venous Vascular Access Devices. 2015 Oct;6(4):100-102.

3. Ista E, van der Hoven B, Kornelisse RF, van der Starre C, Vos MC, Boersma E, et al. Effectiveness of insertion and maintenance bundles to prevent central-line-associated bloodstream infections in critically ill patients of all ages: a systematic review and meta-analysis. Lancet Infect Dis. 2016 Feb;

4. Magder S. How to use central venous pressure measurements. Curr Opin Crit Care. 2005 Jun;11(3):264-270.

5. Magder S. Invasive Hemodynamic Monitoring. Crit Care Clin. 2015 Jan;31(1):67-87.

6. Whiting PF, Rutjes AWS, Westwood ME, Mallett S, Deeks JJ, Reitsma JB, et al. QUADAS-2: A Revised Tool for the Quality Assessment of Diagnostic Accuracy Studies. Ann Intern Med. 2011 Oct;155(8):529-536. 
7. Abbas A, Lester S, Moreno FC, Srivathsan K, Fortuin D, Appleton C. Noninvasive assessment of right atrial pressure using Doppler tissue imaging. J Am Soc Echocardiogr Off Publ Am Soc Echocardiogr. 2004 Nov;17(11):1155-1160.

8. Alimoğlu E, Erden A, Gürsel K, Olçer T. Correlation of right atrial pressure and blood flow velocities in the common femoral vein obtained by duplex Doppler sonography. J Clin Ultrasound JCU. 2001 Feb;29(2):87-91.

9. Arbo JE, Maslove DM, Beraud A-S. Bedside assessment of right atrial pressure in critically ill septic patients using tissue Doppler ultrasonography. J Crit Care. 2013 Dec;28(6):1112.e1-5.

10. Arthur ME, Landolfo C, Wade M, Castresana MR. Inferior vena cava diameter (IVCD) measured with transesophageal echocardiography (TEE) can be used to derive the central venous pressure (CVP) in anesthetized mechanically ventilated patients. Echocardiogr Mt Kisco N. 2009 Feb;26(2):140-149.

11. Avcil M, Kapci M, Dagli B, Omurlu IK, Ozluer E, Karaman K, et al. Comparision of ultrasound-based methods of jugular vein and inferior vena cava for estimating central venous pressure. :9.

12. Baumann UA, Marquis C, Stoupis C, Willenberg TA, Takala J, Jakob SM. Estimation of central venous pressure by ultrasound. Resuscitation. 2005 Feb;64(2):193-199.

13. Belfort MA, Rokey R, Saade GR, Moise KJ. Rapid echocardiographic assessment of left and right heart hemodynamics in critically ill obstetric patients. Am J Obstet Gynecol. 1994 Oct;171(4):884892.

14. Bendjelid K, Romand J-A, Walder B, Suter PM, Fournier G. Correlation between measured inferior vena cava diameter and right atrial pressure depends on the echocardiographic method used in patients who are mechanically ventilated. J Am Soc Echocardiogr Off Publ Am Soc Echocardiogr. 2002 Sep;15(9):944-949.

15. Blair JE, Brennan JM, Goonewardena SN, Shah D, Vasaiwala S, Spencer KT. Usefulness of handcarried ultrasound to predict elevated left ventricular filling pressure. Am J Cardiol. 2009 Jan;103(2):246-247.

16. Bouferrache K, Amiel J-B, Chimot L, Caille V, Charron C, Vignon P, et al. Initial resuscitation guided by the Surviving Sepsis Campaign recommendations and early echocardiographic assessment of hemodynamics in intensive care unit septic patients: a pilot study. Crit Care Med. 2012 Oct;40(10):2821-2827.

17. Brennan JM, Blair JE, Goonewardena S, Ronan A, Shah D, Vasaiwala S, et al. Reappraisal of the Use of Inferior Vena Cava for Estimating Right Atrial Pressure. J Am Soc Echocardiogr. 2007 Jul;20(7):857-861.

18. Cho RJ, Williams DR, Leatherman JW. Measurement of Femoral Vein Diameter by Ultrasound to Estimate Central Venous Pressure. Ann Am Thorac Soc. 2016 Jan;13(1):81-5.

19. Cozcolluela MR, Sarría L, Sanz L, Martinez-Berganza MT, de Vera JM, Bernal A, et al. Correlation of central venous pressure with Doppler waveform of the common femoral veins. J Ultrasound Med Off J Am Inst Ultrasound Med. 2000 Aug;19(8):587-592. 
20. De Lorenzo RA, Morris MJ, Williams JB, Haley TF, Straight TM, Holbrook-Emmons VL, et al. Does a simple bedside sonographic measurement of the inferior vena cava correlate to central venous pressure? J Emerg Med. 2012 Apr;42(4):429-436.

21. Deol GR, Collett N, Ashby A, Schmidt GA. Ultrasound accurately reflects the jugular venous examination but underestimates central venous pressure. Chest. 2011 Jan;139(1):95-100.

22. Donahue SP, Wood JP, Patel BM, Quinn JV. Correlation of sonographic measurements of the internal jugular vein with central venous pressure. Am J Emerg Med. 2009 Sep;27(7):851-855.

23. Duerinckx AJ, Grant EG, Perrella RR, Szeto A, Tessler FN. The pulsatile portal vein in cases of congestive heart failure: correlation of duplex Doppler findings with right atrial pressures. Radiology. 1990 Sep;176(3):655-658.

24. Ghio S, Recusani F, Sebastiani R, Klersy C, Raineri C, Campana C, et al. Doppler velocimetry in superior vena cava provides useful information on the right circulatory function in patients with congestive heart failure. Echocardiogr Mt Kisco N. 2001 Aug;18(6):469-477.

25. Jue J, Chung W, Schiller NB. Does inferior vena cava size predict right atrial pressures in patients receiving mechanical ventilation? J Am Soc Echocardiogr Off Publ Am Soc Echocardiogr. 1992 Nov;5(6):613-619.

26. Keller AS, Melamed R, Malinchoc M, John R, Tierney DM, Gajic O. Diagnostic accuracy of a simple ultrasound measurement to estimate central venous pressure in spontaneously breathing, critically ill patients. J Hosp Med. 2009 Jul;4(6):350-355.

27. Lorsomradee S, Lorsomradee S, Cromheecke S, ten Broecke PW, De Hert SG. Inferior vena cava diameter and central venous pressure correlation during cardiac surgery. J Cardiothorac Vasc Anesth. 2007 Aug;21(4):492-496.

28. Luca L, Mario P, Giansiro B, Maurizio F, Antonio M, Carlo M. Non invasive estimation of mean right atrial pressure utilizing the 2D-Echo transverse diameter of the left hepatic vein. Int $\mathrm{J}$ Card Imaging. 1992;8(3):191-195.

29. Maeder MT, Karapanagiotidis S, Dewar EM, Gamboni SE, Htun N, Kaye DM. Accuracy of Doppler echocardiography to estimate key hemodynamic variables in subjects with normal left ventricular ejection fraction. J Card Fail. 2011 May;17(5):405-412.

30. Marcelino P, Borba A, Fernandes AP, Marum S, Germano N, Lopes MRG. Non invasive evaluation of central venous pressure using echocardiography in the intensive care-specific features of patients with right ventricular enlargement and chronic exacerbated pulmonary disease. Rev Port Pneumol. 2006 Nov;12(6):637-658.

31. Marcelino P, Germano N, Marum S, Fernandes AP, Ribeiro P, Lopes MG. Haemodynamic parameters obtained by transthoracic echocardiography and Swan-Ganz catheter: a comparative study in liver transplant patients. Acta Médica Port. 2006 May;19(3):197-205.

32. Mattioli AV, Castelli A, Mattioli G. Relationship between mean right atrial pressure and Doppler parameters in patients with right ventricular infarction. Clin Cardiol. 2000 Oct;23(10):771-775. 
33. Mintz GS, Kotler MN, Parry WR, Iskandrian AS, Kane SA. Reat-time inferior vena caval ultrasonography: normal and abnormal findings and its use in assessing right-heart function. Circulation. 1981 Nov;64(5):1018-1025.

34. Moreno FL, Hagan AD, Holmen JR, Pryor TA, Strickland RD, Castle CH. Evaluation of size and dynamics of the inferior vena cava as an index of right-sided cardiac function. Am J Cardiol. 1984 Feb;53(4):579-585.

35. Nagdev AD, Merchant RC, Tirado-Gonzalez A, Sisson CA, Murphy MC. Emergency Department Bedside Ultrasonographic Measurement of the Caval Index for Noninvasive Determination of Low Central Venous Pressure. YMEM. 2010 Mar;55(3):290-295.

36. Nageh MF, Kopelen HA, Zoghbi WA, Quiñones MA, Nagueh SF. Estimation of mean right atrial pressure using tissue Doppler imaging. Am J Cardiol. 1999 Dec;84(12):1448-51- A8.

37. Nagueh SF, Kopelen HA, Zoghbi WA. Relation of mean right atrial pressure to echocardiographic and Doppler parameters of right atrial and right ventricular function. Circulation. 1996 Mar;93(6):11601169.

38. Nakao S, Come PC, McKay RG, Ransil BJ. Effects of positional changes on inferior vena caval size and dynamics and correlations with right-sided cardiac pressure. Am J Cardiol. 1987 Jan;59(1):125132.

39. Ommen SR, Nishimura RA, Hurrell DG, Klarich KW. Assessment of right atrial pressure with 2dimensional and Doppler echocardiography: a simultaneous catheterization and echocardiographic study. Mayo Clin Proc. 2000 Jan;75(1):24-29.

40. Patel AR, Alsheikh-Ali AA, Mukherjee J, Evangelista A, Quraini D, Ordway LJ, et al. 3D echocardiography to evaluate right atrial pressure in acutely decompensated heart failure correlation with invasive hemodynamics. JACC Cardiovasc Imaging. 2011 Sep;4(9):938-945.

41. Prekker ME, Scott NL, Hart D, Sprenkle MD, Leatherman JW. Point-of-Care Ultrasound to Estimate Central Venous Pressure. Crit Care Med. 2013 Mar;41(3):833-841.

42. Reeves WC, Leaman DM, Buonocore E, Babb JD, Dash H, Schwiter EJ, et al. Detection of tricuspid regurgitation and estimation of central venous pressure by two-dimensional contrast echocardiography of the right superior hepatic vein. Am Heart J. 1981 Sep;102(3 Pt 1):374-377.

43. Rengo C, Brevetti G, Sorrentino G, D’Amato T, Imparato M, Vitale DF, et al. Portal vein pulsatility ratio provides a measure of right heart function in chronic heart failure. Ultrasound Med Biol. 1998 Mar;24(3):327-332.

44. Sade LE, Gulmez O, Eroglu S, Sezgin A, Muderrisoglu H. Noninvasive estimation of right ventricular filling pressure by ratio of early tricuspid inflow to annular diastolic velocity in patients with and without recent cardiac surgery. J Am Soc Echocardiogr Off Publ Am Soc Echocardiogr. 2007 Aug;20(8):982-988.

45. Said K, Shehata A, Ashour Z, El-Tobgi S. Value of conventional and tissue Doppler echocardiography in the noninvasive measurement of right atrial pressure. Echocardiogr Mt Kisco N. 2012 Aug;29(7):779-784. 
46. Scapellato F, Eleuteri E, Temporelli PL, Imparato A, Corrà U, Giannuzzi P. Doppler-derived acceleration rate of right ventricular early filling as a measurement of right atrial pressure in chronic heart failure secondary to ischemic or idiopathic dilated cardiomyopathy. Am J Cardiol. 1998 Feb;81(4):513-515.

47. Schefold JC, Storm C, Bercker S, Pschowski R, Oppert M, Krüger A, et al. Inferior vena cava diameter correlates with invasive hemodynamic measures in mechanically ventilated intensive care unit patients with sepsis. J Emerg Med. 2010 Jun;38(5):632-637.

48. Simon MA, Kliner DE, Girod JP, Moguillansky D, Villanueva FS, Pacella JJ. Detection of elevated right atrial pressure using a simple bedside ultrasound measure. Am Heart J. 2010 Mar;159(3):421-427.

49. Simonson JS, Schiller NB. Sonospirometry: a new method for noninvasive estimation of mean right atrial pressure based on two-dimensional echographic measurements of the inferior vena cava during measured inspiration. J Am Coll Cardiol. 1988 Mar;11(3):557-564.

50. Siva B, Hunt A, Boudville N. The sensitivity and specificity of ultrasound estimation of central venous pressure using the internal jugular vein. J Crit Care. 2012 Jun;27(3):315.e7-11.

51. Stawicki SP, Braslow BM, Panebianco NL, Kirkpatrick JN, Gracias VH, Hayden GE, et al. Intensivist Use of Hand-Carried Ultrasonography to Measure IVC Collapsibility in Estimating Intravascular Volume Status: Correlations with CVP. ACS. 2009 Jul;209(1):55-61.

52. Sundereswaran L, Nagueh SF, Vardan S, Middleton KJ, Zoghbi WA, Quiñones MA, et al. Estimation of left and right ventricular filling pressures after heart transplantation by tissue Doppler imaging. Am $J$ Cardiol. 1998 Aug;82(3):352-357.

53. Thalhammer C, Aschwanden M, Odermatt A, Baumann UA, Imfeld S, Bilecen D, et al. Noninvasive central venous pressure measurement by controlled compression sonography at the forearm. J Am Coll Cardiol. 2007 Oct;50(16):1584-1589.

54. Thalhammer C, Siegemund M, Aschwanden M, Gassmann M, Baumann UA, Jaeger KA, et al. Noninvasive central venous pressure measurement by compression ultrasound-a step into real life. Resuscitation. 2009 Oct;80(10):1130-1136.

55. Ünlüer EE, Yavaşi Ö, Akoğlu H, Kara HP, Bayata S, Yürekli I, et al. Bedside assessment of central venous pressure by sonographic measurement of right ventricular outflow-tract fractional shortening. Eur J Emerg Med Off J Eur Soc Emerg Med. 2013 Feb;20(1):18-22.

56. Utsunomiya H, Nakatani S, Nishihira M, Kanzaki H, Kyotani S, Nakanishi N, et al. Value of estimated right ventricular filling pressure in predicting cardiac events in chronic pulmonary arterial hypertension. J Am Soc Echocardiogr Off Publ Am Soc Echocardiogr. 2009 Dec;22(12):1368-1374.

57. Yildirimturk O, Tayyareci Y, Erdim R, Ozen E, Yurdakul S, Aytekin V, et al. Assessment of right atrial pressure using echocardiography and correlation with catheterization. J Clin Ultrasound JCU. 2011 Jul;39(6):337-343.

58. Cowie BS, Kluger R, Rex S, Missant C. The relationship between superior vena cava diameter and collapsibility and central venous pressure. Anaesth Intensive Care. 2015;4.

59. Hilbert T, Ellerkmann RK, Klaschik S, Putensen C, Thudium M. The Use of Internal Jugular Vein Ultrasonography to Anticipate Low or High Central Venous Pressure During Mechanical Ventilation. J 
Emerg Med. 2016 Apr;50(4):581-7.

60. Hossein-Nejad H, Mohammadinejad P, Ahmadi F. Internal jugular vein/common carotid artery crosssectional area ratio and central venous pressure: IJV/CCA and CVP. J Clin Ultrasound. 2016 Jun;44(5):312-8.

61. Karacabey S, Sanrı E, Guneysel O. A New Formula for Non-invasive Assessment of Intravascular Fluid Status with Inferior Vena Cava Diameters and Collapsibility Index: A Pilot Study. Pak J Med Sci [Internet]. 1969 Dec 31 [cited 2018 Aug 5];32(4). Available from:

http://pjms.com.pk/index.php/pjms/article/view/10290

62. Kawata T, Daimon M, Lee SL, Kimura K, Sawada N, Chiang S-J, et al. Reconsideration of Inferior Vena Cava Parameters for Estimating Right Atrial Pressure in an East Asian Population - Comparative Simultaneous Ultrasound-Catheterization Study —. Circ J. 2017;81(3):346-52.

63. Lee SL, Daimon M, Kawata T, Kohro T, Kimura K, Nakao T, et al. Estimation of Right Atrial Pressure on Inferior Vena Cava Ultrasound in Asian Patients. Circ J. 2014;78(4):962-6.

64. Muhamad NAN. Internal Jugular Vein Height and Inferior Vena Cava Diameter Measurement using Ultrasound to Determine Central Venous Pressure: A Correlation Study. 2015;70(2):4.

65. Naghipour B, Faridaalaee G. Correlation between Central Venous Pressure and Inferior Vena Cava Sonographic Diameter; Determining the Best Anatomic Location. :5.

66. Sobczyk D, Nycz K, Andruszkiewicz P. Bedside Ultrasonographic Measurement of the Inferior Vena Cava Fails to Predict Fluid Responsiveness in the First 6 Hours After Cardiac Surgery: A Prospective Case Series Observational Study. J Cardiothorac Vasc Anesth. 2015 Jun;29(3):663-9.

67. Stawicki SPA, Adkins EJ, Eiferman DS, Evans DC, Ali NA, Njoku C, et al. Prospective evaluation of intravascular volume status in critically ill patients: Does inferior vena cava collapsibility correlate with central venous pressure? J Trauma Acute Care Surg. 2014 Apr;76(4):956-64.

68. Tsutsui RS, Borowski A, Tang WHW, Thomas JD, Popović ZB. Precision of Echocardiographic Estimates of Right Atrial Pressure in Patients with Acute Decompensated Heart Failure. J Am Soc Echocardiogr. 2014 Oct;27(10):1072-1078.e2.

69. Worapratya P, Anupat S, Wuthisuthimethawee P, Suwannanon R. Correlation of caval index, inferior vena cava diameter, and central venous pressure in shock patients in the emergency room. Open Access Emerg Med. 2014 Aug;57.

70. Michaux I, Filipovic M, Skarvan K, Schneiter S, Seeberger MD. Accuracy of tissue Doppler estimation of the right atrial pressure in anesthetized, paralyzed, and mechanically ventilated patients. Am J Cardiol. 2006 Jun;97(11):1654-1656.

71. Bodson L, Vieillard-Baron A. Respiratory variation in inferior vena cava diameter: surrogate of central venous pressure or parameter of fluid responsiveness? Let the physiology reply. Crit Care. 2012;16(6):181.

72. Lang RM, Badano LP, Mor-Avi V, Afilalo J, Armstrong A, Ernande L, et al. Recommendations for Cardiac Chamber Quantification by Echocardiography in Adults: An Update from the American 
Society of Echocardiography and the European Association of Cardiovascular Imaging. Eur Heart J Cardiovasc Imaging. 2015 Mar;16(3):233-271.

73. Magder S. Bench-to-bedside review: An approach to hemodynamic monitoring - Guyton at the bedside. Crit Care. 2012;16(5):236.

\section{Tables}

Table 1: Characteristics of Studies Reporting_IVC Size

\begin{tabular}{|c|c|c|c|c|c|c|c|c|c|c|c|c|c|}
\hline Aut hors: & Year & Setting & $\begin{array}{c}\text { U/S } \\
\text { madality }\end{array}$ & User & patients & Age & $\begin{array}{l}\text { Primary } \\
\text { diagnasis }\end{array}$ & Intubated & cs & Deby & R value & $\begin{array}{l}\text { Quality } \\
\text { Scare }\end{array}$ & $\begin{array}{l}\text { Quality } \\
\text { Rating }\end{array}$ \\
\hline Aethue ME & 2000 & X.U. & TE & Aldoseh & 85 & 57 & CS & Yos & Yos & 0.5 & 0.86 & 8.5 & High \\
\hline Aved M & 2016 & xu & rocus & $\mathrm{xu}$ & 73 & 64 & Supsis & $M x$ & $\boldsymbol{\omega}$ & en & 0.20 & 7 & Hiqh \\
\hline Bulfoent MA & 1904 & x.u & TE & Undvar & 11 & 25 & Selpsis & Mes & No & 0.5 & 0.87 & 10.5 & Ines \\
\hline Bund jelid K & 2002 & xu & TE & MTU & 20 & 62 & Sepsis & Yas & No & 0.9 & 0.81 & 8.5 & High \\
\hline Bund jelid $K$ & 2002 & X.u & $\pi E$ & siru & 20 & 62 & Serpoxis & ras & No & 0.5 & 0.71 & 8.5 & Migh \\
\hline Blair JE & 2000 & Cambio & MHUS & Cardio & 72 & 50 & N/A & No & No & ith & W/A & 8 & High \\
\hline Eremais IM & 2007 & Cardie & TE & Cardio & 91 & 50 & af & No & No & at & 0.50 & 10 & High \\
\hline Erentinat JM & 2007 & Cardie & $\Gamma E$ & Cientio & 9 & 50 & orf & No & No & in & 0.60 & 10 & High \\
\hline Eremenas JM & 2007 & Candio & $\mathrm{rE}$ & Cartio & 91 & 50 & orf & No & No & in & 0.60 & 10 & High \\
\hline De Lerenve RA.A & $2 \cos 2$ & Ele xu & roc & MTU & 65 & 67 & kf & Mex & $\omega_{0}$ & 0.9 & 0.51 & 19 & Low \\
\hline De Leremino R.A & 2012 & EN Ku & Noc. & stru & 65 & 67 & RF & Mas & No & 0.5 & 0.45 & 19 & Low \\
\hline De Lerenve RAA & 20022 & Ever $x$ & $\mathrm{rec}$ & NITU & 65 & 67 & inf & $M x$ & No & 0.9 & 0.50 & 19 & Low \\
\hline twe d & $190 / 2$ & K.u & TE & Cuedio & 49 & 58 & RF & Yos & Yes & 0.5 & 0.58 & 9 & Migh \\
\hline Karacibey S & 2016 & Ex & rocus & $\mathrm{ER}$ & 83 & 73 & Sepsis & Yas & wo & $N / A$ & 0.53 & 10 & Migh \\
\hline Sawata T & 2017 & Canclio & TE & Cardie & 120 & 54 & OF & No & wo & on & 0.47 & 8 & High \\
\hline Lee SL & 2014 & Cartio & $\pi E$ & Cardio & 360 & 56 & GF & No & No & $24 \mathrm{~h}$ & N/A & 12 & Ins \\
\hline Lexwomnadere S & 2007 & OR & TE & Anessh & $\pi 0$ & 68 & cs & Yas & Yes & $N / A$ & 0.81 & 8 & High \\
\hline Marceline " & 2006 & $\mathrm{xu}$ & $\pi E$ & Undear & 477 & 62 & Sopsis & $M x$ & No & 0.5 & $N / 2$ & 7.5 & High \\
\hline Minu CS & 1961 & Cardio & $\pi$ TE & Cardio & 50 & $N / A$ & 아 & $N / A$ & N/A & $N / A$ & 0.72 & 12 & Ines \\
\hline Moriatio of & 1964 & Cardio & TE & Cardio & 65 & 46 & Orf & No & wo & $24 h$ & 0.40 & 13 & Ine \\
\hline Muldimad N & 2005 & Ex & rocus & $E R$ & 25 & 60 & Seppexs & No & No & on & 0.74 & 8 & Migh \\
\hline Naquder $A D$ & 2010 & Ex & poc & MTu & 73 & 63 & N/A & Ms & No & 0.9 & 0.78 & 2.5 & Migh \\
\hline Magdev AD & 2000 & ER & noc & MTu & 73 & 63 & N/A & $M=$ & No & 0.5 & 0.65 & 2.5 & High \\
\hline Naqhipecur $\mathbf{B}$ & 2016 & Cartio & TE & Cartio & 30 & 62 & N/A & No & No & $\mathrm{ch}$ & 0.85 & 7 & High \\
\hline Nakae S & 1987 & Candio & TE & Cardio & 53 & 56 & CAO & No & wo & $24 \mathrm{~s}$ & 0.57 & 10 & High \\
\hline Omimens & 2000 & Cartio & $\pi E$ & Corctio & $n$ & 56 & orf & No & $N_{0}$ & 0.5 & N/A & 2.5 & Migh \\
\hline Dabel AR & 2001 & $\mathrm{Cou}$ & $\mathrm{rE}$ & Cardio & 40 & 53 & Orf & No & No & 0.5 & 0.56 & 10 & Migh \\
\hline Drekker ME & 2003 & 100 & Moc & NTU & 65 & 59 & Sepsis & No & No & 0.9 & 0.76 & 2.5 & High \\
\hline Semoleld $\mathrm{XC}$ & 2000 & x.u & NoC & stru & 30 & 60 & Serpous & $\mathrm{ras}$ & No & 0.9 & 0.56 & 7.5 & Mig̨h \\
\hline Simbentsent I) & 1988 & Cardio & TE & Cardio & 27 & $N / A$ & OFf & No & $\omega$ & $N / A$ & 0.35 & 13.5 & Ins \\
\hline Tseubsuat RS & 2014 & Candio & TE & Cardio & $n$ & 56 & orf & No & No & on & 0.40 & 10 & High \\
\hline Utsuntomiza H & 2000 & Cardio & rE & Cardio & 50 & 46 & DAC & No & No & $24 \mathrm{~h}$ & 0.6 & 11.5 & Int \\
\hline 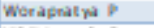 & 2014 & Ex & rocus & $\mathrm{B}$ & 30 & $N / A$ & Supsess & No & No & on & 0.551 & 7 & High \\
\hline Yildrims unk 0 & 2001 & Cardio & $\mathrm{TE}$ & Cardio & 30 & 59 & MS & No & No & 0.5 & 0.51 & 12.5 & Ins \\
\hline
\end{tabular}

Table 2: Characteristics of Studies Reporting_IVC Collapsibility

\begin{tabular}{|c|c|c|c|c|c|c|c|c|c|c|c|c|c|}
\hline Aut hars & Year & Setting & $\begin{array}{c}\text { U/S } \\
\text { madality }\end{array}$ & User & $\begin{array}{c}z \\
\text { Patiants }\end{array}$ & Age & $\begin{array}{l}\text { Primary } \\
\text { diagnesis }\end{array}$ & Intubeted & cs & Deby & R value & $\begin{array}{l}\text { Qualty } \\
\text { Scare }\end{array}$ & $\begin{array}{l}\text { Qudify } \\
\text { Reting }\end{array}$ \\
\hline Rowkker ME & 2613 & ICu & NCC. & Mrtu & 65 & 50 & Supses & No & No & 0.5 & .0 .40 & 2.5 & Hich \\
\hline habel Ak & 2011 & $\mathrm{COU}$ & TE & Ciatio & 40 & 53 & OF & No & No & 0.9 & .0 .49 & 10 & High \\
\hline Yildrimbuate o & 2001 & Cartio & TE & Cardio & 30 & 50 & MS & No & No & 0.5 & 0.56 & 12.5 & les \\
\hline Naquder AD & 2000 & Ex & noc & NTU & 73 & 63 & N/A & Max & No & 0.9 & -0.67 & 2.5 & Migh \\
\hline Usiantomera H & 2000 & Cantio & $\pi E$ & Carbio & 50 & 46 & RAT & No & No & $24 \mathrm{~s}$ & .0 .60 & 11.5 & Ins \\
\hline Sawicki S & 2000 & $\mathrm{xu}$ & Noc & NITU & 101 & 58 & Surqual & Mx & No & 0.9 & -6.32 & 8 & Migh \\
\hline Gair JE & 2000 & Cardio & HMUS & Cardio & $n$ & 50 & N/A & No & No & is & N/A & 8 & Migh \\
\hline Erentinat JM & 2007 & Candio & rE & Cientio & \% & se & Orf & No & No & ih & .0 .50 & 10 & Might \\
\hline Eermenas JM & 2007 & Candio & mE & Cardio & 91 & 50 & Orf & No & No & it & .0 .50 & 10 & Migh \\
\hline Marceline ? & 2006 & XU & $\pi E$ & unclest & 477 & 62 & Sepsus & $M x$ & * & 0.5 & N/A & 7.5 & Migh \\
\hline Maguveh SF & 1906 & x.u & TIE & Cardio & 35 & 60 & SAH & Mex & Yes & 0.5 & .0 .63 & 8 & Migh \\
\hline The 1 & 102 & $\mathrm{xu}$ & TE & Ciatio & 49 & 58 & sf & Yas & Yes & 0.9 & 0.13 & 9 & Hight \\
\hline Nakao S & 1987 & Candio & $\pi E$ & Circlio & 53 & 56 & CAO & No & w & $24 h$ & .0 .48 & 10 & Migh \\
\hline Mor diso f & 1964 & Cardio & $\pi \mathrm{T}$ & Cirdio & 65 & 46 & OFf & No & No & $25 \mathrm{~h}$ & 0.71 & 13 & Int \\
\hline Karacabey S & 2016 & Ex & 10cus & ER & 83 & 73 & sepsis & AI & $\infty$ & $N / A$ & 0.72 & 10 & High \\
\hline Kawata T & 2007 & Cambio & TE & carfio & 120 & 54 & लF & No & No & $\mathrm{Ch}$ & .6 .40 & 8 & Hah \\
\hline LeE SL & 2014 & Cantio & TIE & Cardio & 360 & 56 & off & No & wo & $24 \mathrm{a}$ & N/A & 12 & Ins \\
\hline Sebcayk o & 2015 & $x \mathrm{Cu}$ & rocus & $\mathrm{xu}$ & so & 64 & CS & AI & Yas & en & 6.19 & 9 & Hight \\
\hline Stawidki S & 2014 & xu & $100 \mathrm{~s}$ & xu & $\infty$ & 56 & $s$ & Ms & vo & Ch & 0.42 & 9 & Migh \\
\hline Worapnat pa p & 2014 & Ex & rocus & ER & 30 & $N / A$ & Sepsus & No & No & ch & -0.72 & 7 & High \\
\hline
\end{tabular}


Table 3: Characteristics of Studies Reporting_Non-IVC Parameters

\begin{tabular}{|c|c|c|c|c|c|c|c|c|c|c|c|c|c|c|}
\hline CVP Compe rater & Authors & Year & Settima & $\begin{array}{c}\text { U/S } \\
\text { modiality }\end{array}$ & Unar & a Patiemts & Age & $\begin{array}{l}\text { Primary } \\
\text { diegnasis }\end{array}$ & Intubeted & cs & Dulby & R welue & $\begin{array}{l}\text { Quelity } \\
\text { Scares }\end{array}$ & $\begin{array}{l}\text { Quality } \\
\text { Rating }\end{array}$ \\
\hline TV E/E & Tsedsul los & 2014 & Cardo & re & Cardo & $n$ & 56 & CHE & No & No & a & 0.19 & $\boldsymbol{x}$ & High \\
\hline TV E/E' & Said K & 2002 & $\propto c u$ & $\pi E$ & Cardo & 50 & 50 & ACS & No & No & a.s & 0.84 & 13.5 & la \\
\hline W E E/E & hed All & 2011 & $\propto c u$ & TE & Carto & N/A & 53 & CHE & No & No & 0.5 & 0.00 & so & Migh \\
\hline TN $E / E$ & Sade LE & 2007 & $x$ & TEE & Cartén & 101 & 60 & 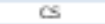 & $M x$ & Yes & N/A & 0.70 & 8.5 & Hich \\
\hline TV E/E & sade LE & 2007 & $\mathrm{xau}$ & TE & Carte & 53 & 63 & xu & Mx & No & $N / A$ & 0.83 & 85 & High \\
\hline TV EIE & Sade Lf & 2007 & 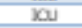 & $\pi E$ & Condo & 36 & 56 & $\mathrm{cs}$ & $M x$ & Yes & N/A & 0.41 & 85 & Migh \\
\hline TN E/Ea & Mohause I & 2006 & ox & TEE & Alwsels & 44 & 63 & $\Phi$ & Nes & Yes & 0.5 & .0 .11 & 2.5 & Hiqh \\
\hline TV E/Ea & Naquh MF & 1000 & Cardo & TE & Cardo & 62 & 68 & $\mathrm{CAO}$ & $4 x$ & No & a.s & 0.75 & 25 & Migh \\
\hline TV E/Ea & Suntoinusimanas L & 1908 & Cardo & $n=$ & Cordo & 38 & 53 & HI & Nus & Yes & N/A & 0.5 & 20.5 & Migh \\
\hline TV E/Ea & $A=101$ & 2003 & xas & $10 \mathrm{C}$ & MIU & 30 & 62 & Soptis & $M x$ & No & as & N/A & 85 & Hiqh \\
\hline TV E/A nabo & had as & 2011 & CCu & ne & $\cos 60$ & 17 & 53 & $\mathrm{CH}^{*}$ & No & No & 25 & 0.57 & $\mathbf{D}$ & Migh \\
\hline W E/A nabo & 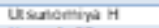 & 200 & Cardo & $\mathrm{TE}$ & Getoso & 50 & 46 & Wस & No & No & $24 h$ & 0.800 & 11.5 & In \\
\hline TV E/A nabio & Maquen SF & 1906 & $\mathrm{xau}$ & TEE & Cardio & 35 & 60 & SaH & M. & Yes & 0.5 & 0.66 & 8 & Hight \\
\hline Nercherad Wen & Thallowemer $C$ & 2000 & $x$ & noc & sTu & so & 67 & $\propto$ & Mx & Yes & N/A & 0.62 & 8.5 & High \\
\hline Nerehar id win & Talloumener $C$ & 2007 & $\mathrm{xu}$ & cus? & stru & 50 & 60 & Seppis & Me & No & N/A & 0.84 & 8 & Hiqh \\
\hline Ferchere d Wen & Eaumatin ua & 2005 & $x$ & $10 \mathrm{C}$ & NTIU & 32 & 60 & es & $M x$ & undear & e.s & N/A & 8 & Migh \\
\hline D keight & Awal M & 2016 & ow & $10 C$ & x.u & 73 & 64 & Supus & $M=$ & No & a & 0.66 & 7 & High \\
\hline D reigh & Mulvartuad N & 20015 & $E$ E & pocus & Ek & 25 & 60 & Sepus & 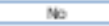 & 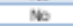 & a & 0.64 & 8 & Migh \\
\hline$D \operatorname{sen}$ & Awal M & 2006 & $\mathrm{xad}$ & nocus & X.u & 73 & 64 & Supuis & $M x$ & No & a & 0.54 & 7 & Hiqh \\
\hline D $\sin$ & 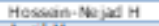 & 2016 & Ex & rocus & El & 52 & 58 & Sepus & $\$$ & No & a & 0.44 & 2 & Hiqh \\
\hline II $x<a$ & Aval M & 2016 & Xas & Wous & X.u & 73 & 64 & Seppis & M. & No & क & 0.50 & 7 & Migh \\
\hline Dived & 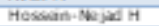 & 2016 & $E x$ & Nocus & Ek & 52 & 98 & Soptis & No & 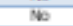 & के & 0.63 & 5 & Miqh \\
\hline D REAVCCA rabo & Hossade - Meject H & 2016 & ER & hous & $E$ & 52 & 58 & Sepper & wo & wo & क & 0.74 & 9 & Migh \\
\hline 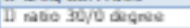 & Holbent $Y$ & 2016 & Xav & Fous & Dowivish & 47 & 68 & $s$ & Nis & Yes & के & N/A & 9 & Hiqh \\
\hline SWC collapsublity & Cowie es & 2015 & $\mathrm{xar}$ & TEE & Alwsala & 91 & 60 & $\Phi$ & All & Yes & a & -0.21 & 9 & High \\
\hline $\operatorname{SNC} \sin$ & Cowie es & 2005 & $x$ & TEE & Anvivath & in & 60 & 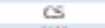 & All & Yes & a & 0.04 & 2 & High \\
\hline Fumbeal ven fiamed or & Wo kd & 2006 & $\mathrm{xu}$ & nocus & $\mathrm{xuu}$ & 97 & 59 & N/A & All & wo & N/A & 0.66 & is & lat \\
\hline
\end{tabular}

Table 4: Characteristics of Studies Reporting_Binary IVC Parameters

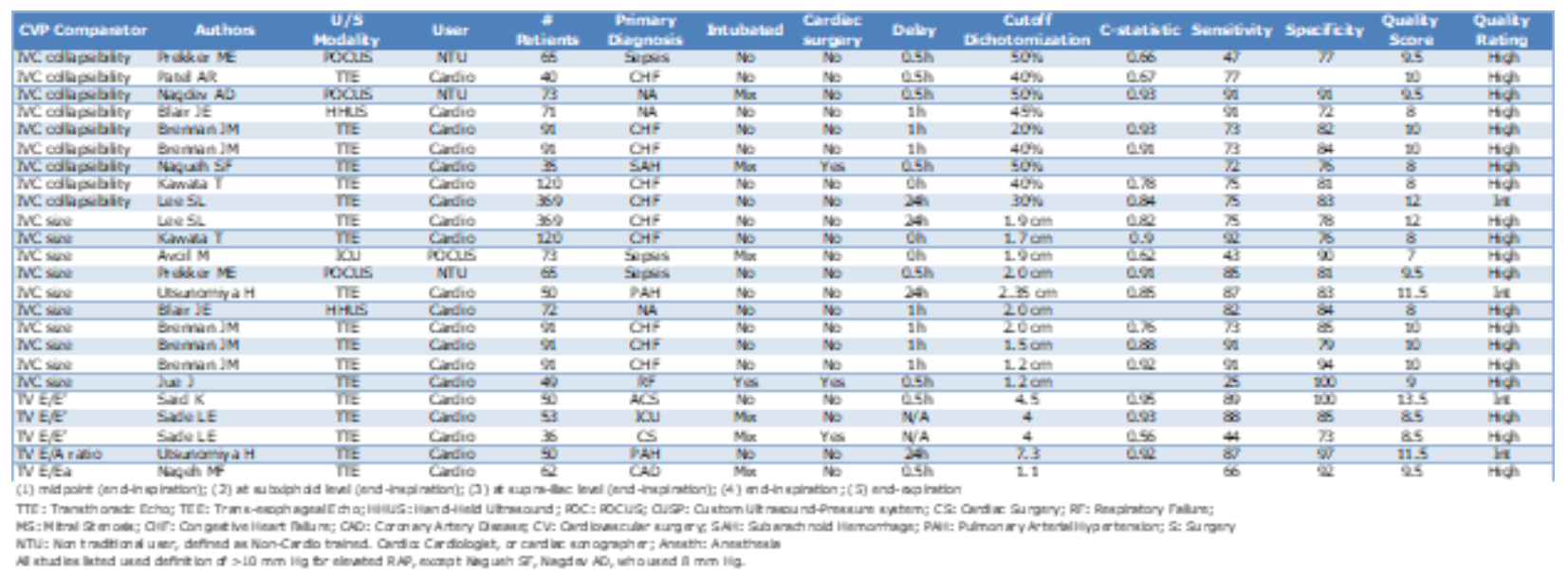

Figures 


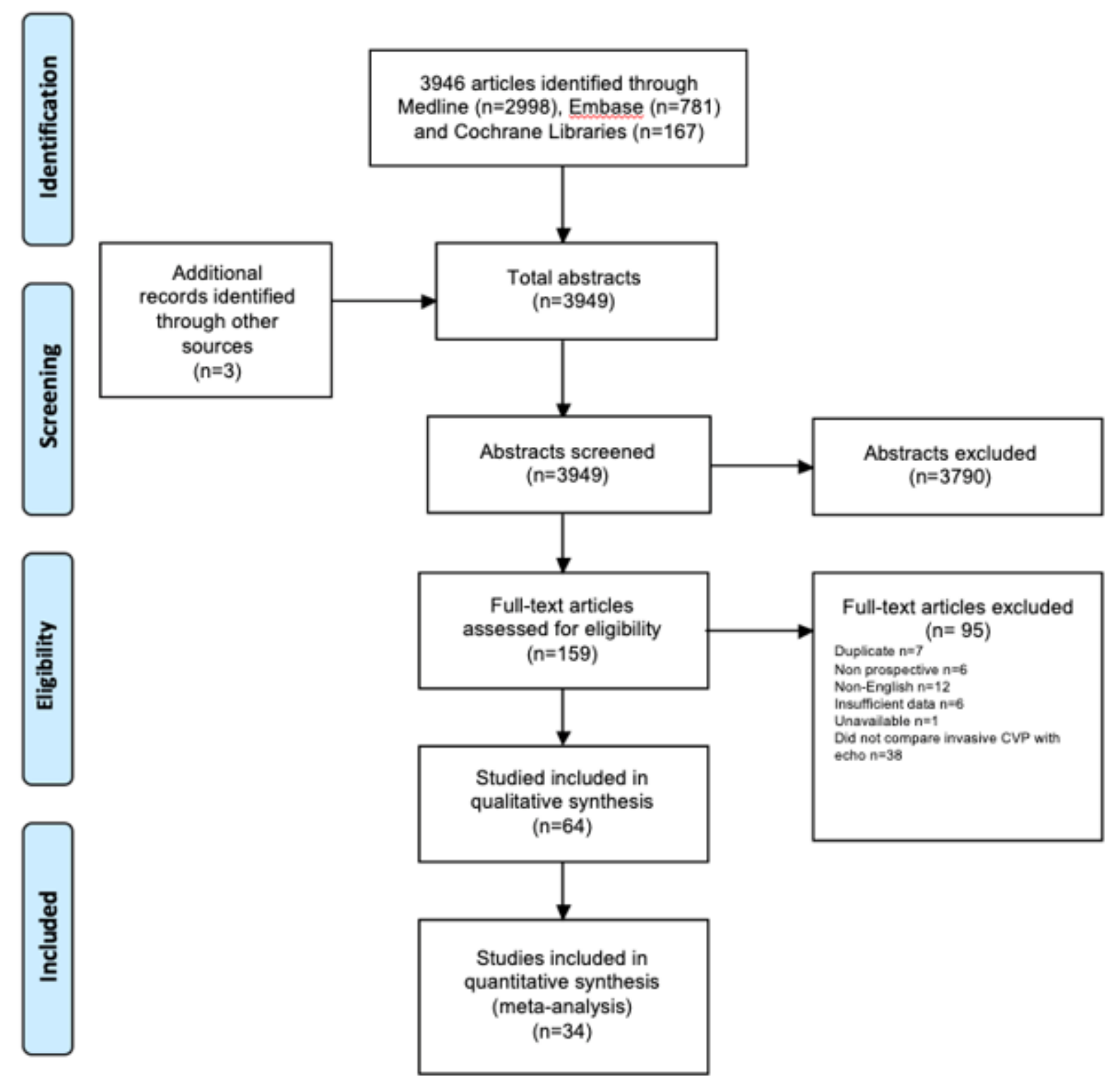

Figure 1

Flow Diagram 


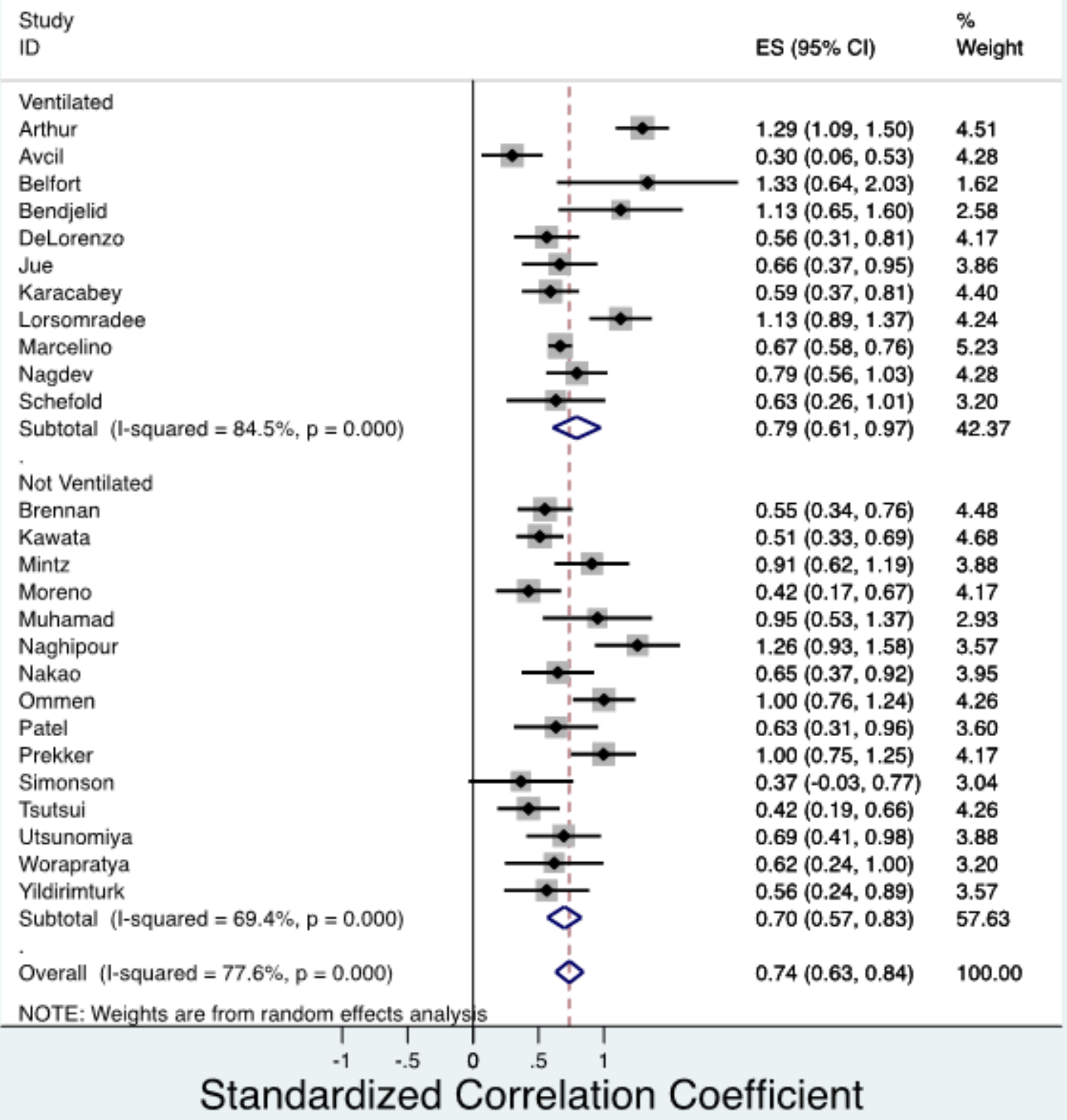

Figure 2

Forest Plot for Echocardiographic IVC Diameter and Invasive CVP 


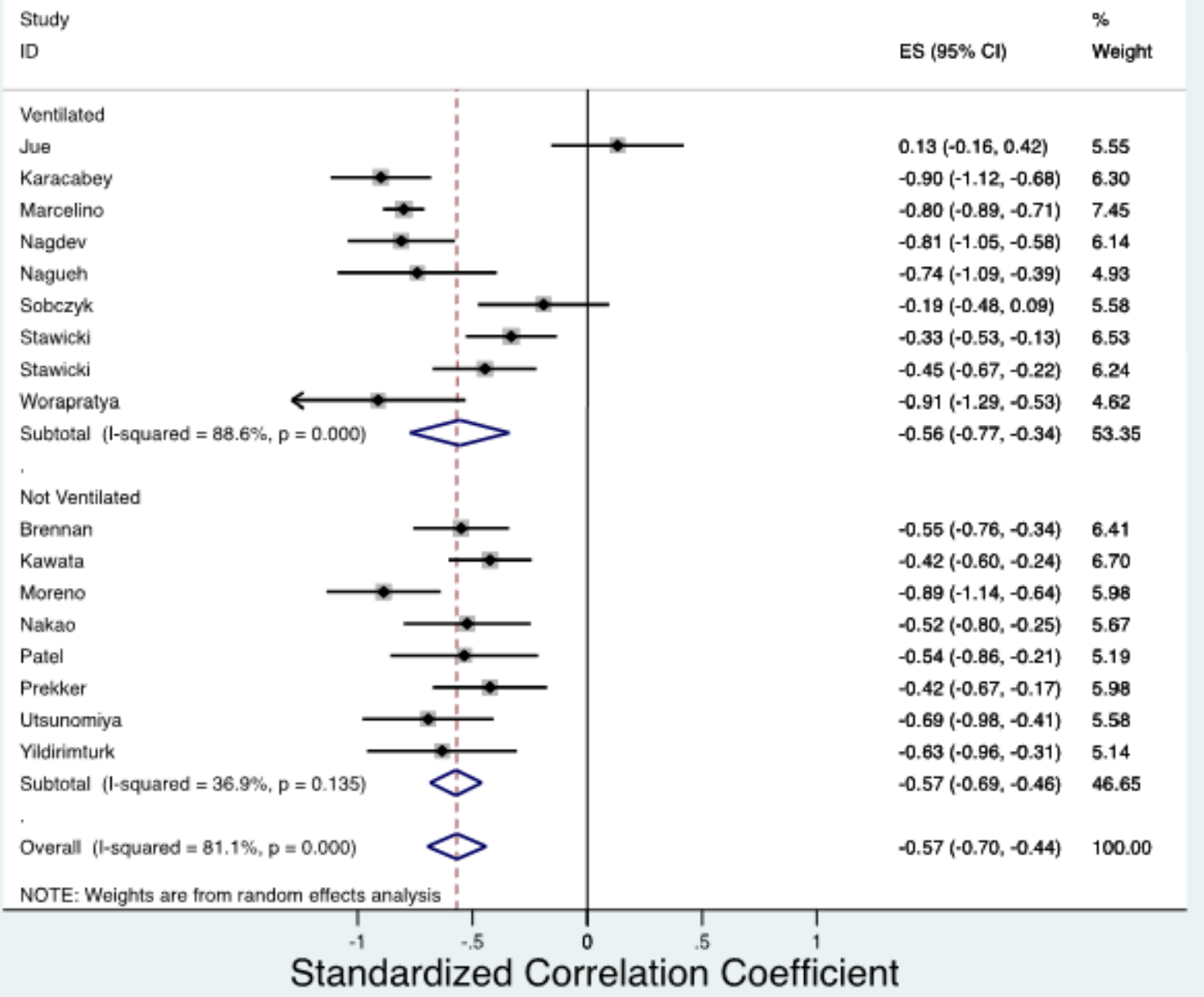

\section{Figure 3}

Forest Plot for Echocardiographic IVC Collapsibility and Invasive CVP 


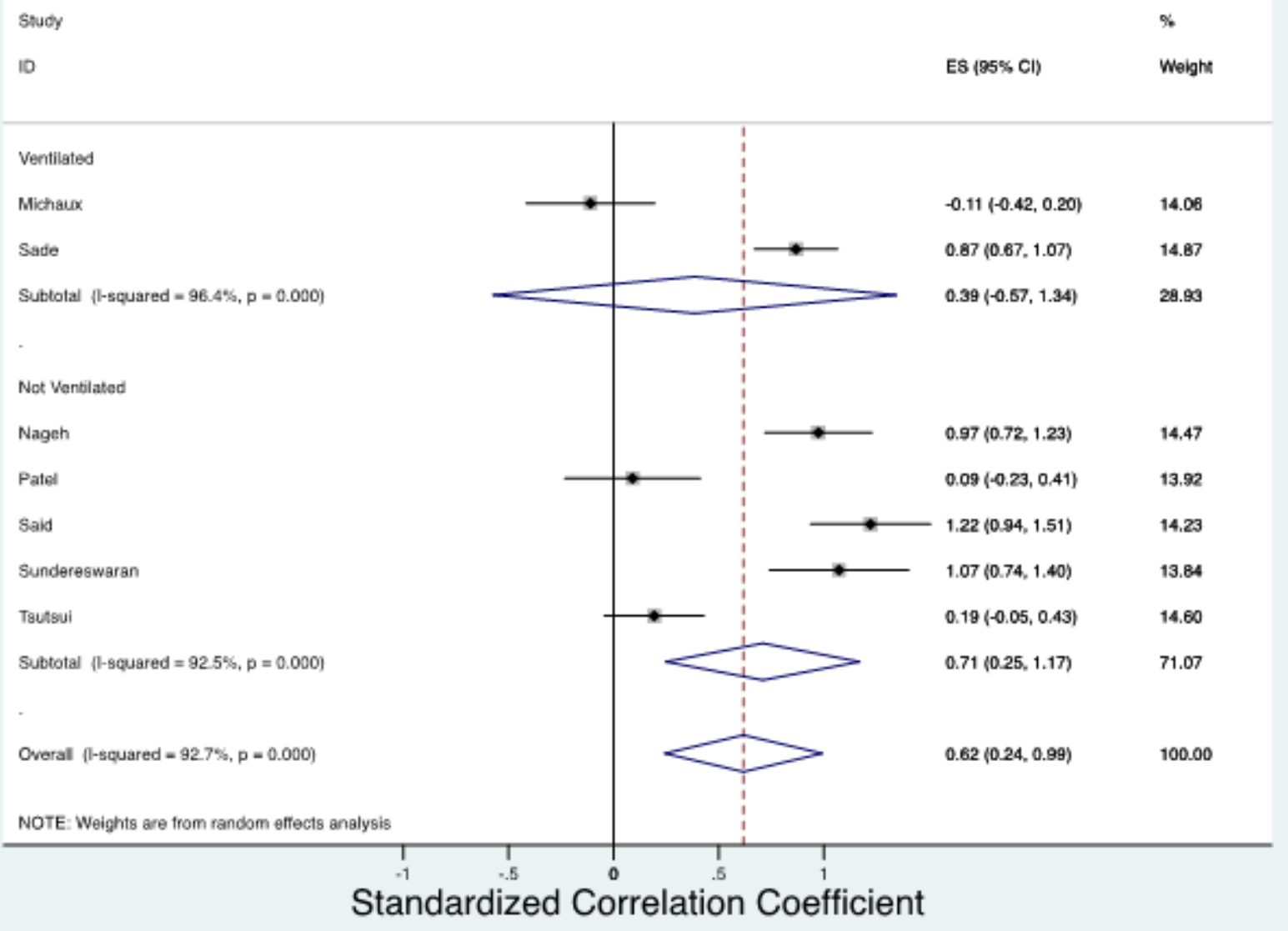

Figure 4

Forest Plot for Echocardiographic E/Ep Ratio and Invasive CVP 